\title{
"A Thorough Study of the Spanish Influenza": How Japanese Party Politics and Ministerial Conflicts Reduced the Pandemic
}

Juhee Kang*

\section{Introduction}

On October 23, 1918, the Bureau of Public Hygiene, under the Home Ministry, published a report on the virulent cold spreading fast around the empire. The report described it as "Grippe" or "Spanish Influenza," terms respectively referring to the respiratory pandemic in the $18^{\text {th }}$ century Europe and the influenza outbreak striking major cities at the time.

The report was the first official document on the subject that came out of a series of inter-ministerial telegraph correspondences. On October 9, the Ministry of Foreign Affairs sent the initial telegraph, alarming the Home Ministry that a fever disease, swirling in Europe, may arrive in mainland Japan. A week later, the Navy substantiated that two or three thousand people in Southern Russia were dying of symptoms of high fever, sudden heart attack, and pneumonia. Shortly, the minister of Foreign Affairs informed other ministers that major ports were now under temporary quarantine. On the twentieth, he forwarded the telegraphs from the Japanese embassies in San Francisco, Shanghai, and Hong Kong, reporting the flu outbreak in Canada, the United States, Ningbo, and India. The

* Ph.D. Candidate, Department of East Asian Languages and Civilizations, Harvard University, Cambridge, MA, USA. 
Bureau of Public Hygiene announced a significant number of patients and deaths in three prefectures and ordered the closing of schools, factories, and local organizations at the governors' discretion. ${ }^{1}$

This marked the beginning of the furtive chain of command that attempted to alleviate the damage from the Spanish Influenza from 1918 to 1920. Counting those who died of its complications, the Spanish flu scythed the lives of more than 481,000 people in mainland Japan alone. ${ }^{2}$ The number of estimated deaths in the colonies was around 191,048, racking the average mortality rate to $1.38 \%{ }^{3}$ Beyond the Japanese Empire, the flu baffled the best medical science experts at the time. In fact, only in 1931, the causative agent, the flu virus, was discovered, and the Spanish Influenza was found to be the predecessor of all subsequent swine flus. ${ }^{4}$ On top of the pneumonic complications that killed the youngest and the oldest, the flu caused the cytokine storm. The storm induced the strongest immune systems in people of their twenties and thirties to overreact and asphyxiated them. This loss of core productive and reproductive labor forces directly translated into a drop in annual population growth rate from 12.47 in 1917 to 5.89 in 1918 . Only in 1920

1 Naimushō Eiseikyoku (Bureau of Public Hygiene, Home Ministry), Ryukōsei Kanbō: 'Supein Kaze' Dairyūkō no Kiroku (The Contagious Cold: The Documentation of the Pandemic Spanish Influenza) (December 1921; repr., Tokyo: Heibonsha 2008), 104-7.

2 S. A. Richard, N. Sugaya, L. Simonsen, M. A. Miller and C. Viboud, "A Comparative Study of the 1918-1920 Influenza pandemic in Japan, USA and UK: mortality impact and implications for pandemic planning," Epidemiology \& Infection 137, issue 8 (August 2009): 3.

3 For Korea and Taiwan, please see these articles. Kim Taek-joong, "1918nyŏn Tokkamgwa Chosŏnch'ongdokpu Pangyŏkchŏngch'aek (The 1918 Influenza Pandemic and Japanese Government-General of Korea's Preventive Measures against Epidemics)," Inmun Nonchong 74, no. 1 (February 2017): 173-5; Ying-Hen Hsieh, "Excess Deaths and Immunoprotection during 1918-1920 Influenza Pandemic, Taiwan," Emerging Infectious Diseases 15, no. 10 (October 2009): 1617-9.

4 Heather L. Epps, "Influenza: exposing the true killer," The Journal of Experimental Medicine 203, no. 4 (April 2006): 803. 
did the rate recover to $11.96 .^{5}$ As such, the flu posed an unprecedented challenge when the empire was at the height of flaunting its speedy modernization.

The late 1910 s and early 1920 s was indeed the period when Japan established itself as a "civilized" empires. Since the Meiji Restoration in 1868, the state led a wholescale, top-down reformation. It abolished the status system, executed nationwide tax and land reforms, and invited French and German specialists to reorganize the legal system, administration, and military. It also sponsored the children of the former samurai families to study abroad and bring back the most updated knowledge and techniques of science and medicine. All these efforts crystalized in a series of military feats and international recognition. After the first SinoJapanese war (1894-1895), Japan acquired its first colony, Taiwan and solidified its prominence over "the sick man of Asia." At the turn of the century, Great Britain, the United States, and Germany revised their unequal treaties at Japan's will. The Russo-Japanese war in 1905 further marked a historical victory of the non-white race over white Russians, and by the 1910s, with the colonial acquisition of the Korean peninsula, the Japanese Empire presided as "the only modern civilization in Asia.",

Scholars of modern Japan long examined the relationship between Japan's modernization and the state's role. Particularly in the 1980s, they focused on the modern state as the mastermind in building the economic structure and begetting the labor-intensive corporate culture that remained critical to Japan's postwar resurgence as the second largest economy in the world. Chalmers Johnson argues that from the early 1920s, the Minis-

5 Naikaku Tokeikyoku (Imperial Cabinet, Department of Statistics), ed., Nihon Teikoku Tōkei Tekiyō (Statistical Summary of the Empire of Japan), Vol. 37 (Tokyo: Tokyo Statistics Association, 1923).

6 Words of Fukuzawa Yukichi (1835 -1901). He was a prominent social reformer, author, translator, and journalist whose works influenced Japanese self-perception in late 19th century. He is considered the most important thinker of modern Japan and also supported Kitasato Shibasaburo who will appear later in this paper to establish the Institute for Study of Infectious Diseases. 
try of Trade and Industry (MITI), membered with economists who advocated a state-controlled market economy, maximized the trade benefit by allocating the rights of foreign trade to different companies and preventing unnecessary competitions. ${ }^{7}$ On the other hand, Sheldon Garon asserts that the Home Ministry colluded the political parties to expediently repress social problems. He illustrates how the political party members shared official positions in the state bureaucracy, and they were often not in the best interest of the working-class. ${ }^{8}$ While scholars had disagreed on the scope and implications of bureaucratization, they concur on the importance of the state in building a modern Japan. Central to the claim is the sense that from early on, the structure of the state bureaucracy was considerably stable.

The perception of structural stability was also a self-perpetuating one by the Japanese state and the ministries. Painted in 1890, The illustration of the Imperial Diet of the House of Representatives captures how the Meiji government imagined and portrayed themselves. In the balcony, the symbolic head, emperor and numerous faceless ministerial bureaucrats oversee the elected party politicians, all in Western style suits. Promoting an image of a modern state, the illustration conveys a fully formed and well-organized polity and a close proximity between bureaucracy and party politics.

In addition, already in the early $20^{\text {th }}$ century, many government ministries claimed to serve Japan's modernization in their full maturity. Conveying the sense of structural stability was key to their claims. They often published the thirtieth anniversary or semi-centennial histories to highlight their accomplishments and gain general recognition. The preface of the 1923 semi-centennial history of the Home Ministry explains that the ministry "hopes to educate the imperial subjects of the importance and

7 Chalmers Johnson, MITI and the Japanese Miracle: The Growth of Industrial Policy: 1925-1975 (Stanford: Stanford University Press, 1982).

8 Sheldon Garon, The State and Labor in Modern Japan (Berkeley: University of California Press, 1987). 


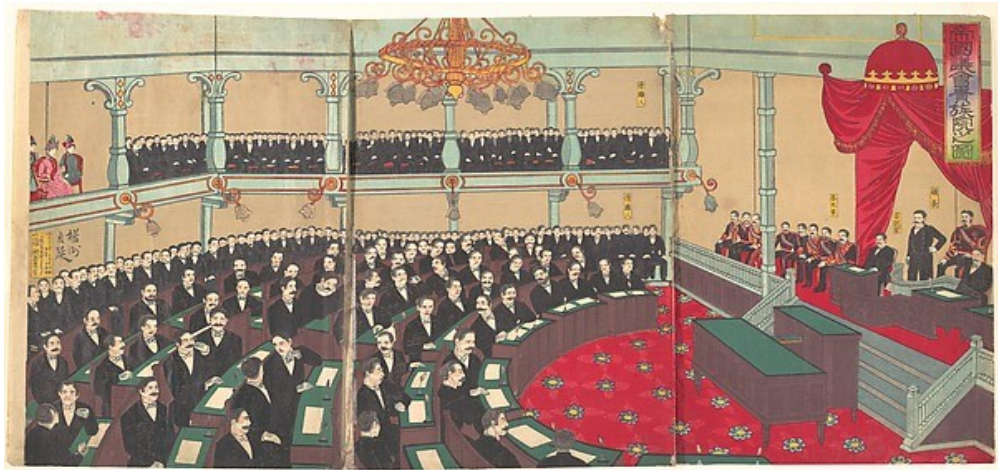

The illustration of the Imperial Diet of the House of Representatives by Hashimoto Chikanobu in 1890. Courtesy of the Metropolitan Museum of Art of New York

various roles" it had heretofore played. ${ }^{9}$ In portraying the development of the bureaucratic structure and the operation system, the ministry tells a story with no cacophony, in which early inter-ministerial conflicts were ironed out. Other ministerial histories narrate similar stories. The bureaus, subordinate to the ministry, also published such histories with a highlight on their main agendas. For instance, in 1925, the Bureau of Public Hygiene under the Home Ministry printed The Fifty Years' History of the Medical System, emphasizing the Bureau's leadership in regulating modern medicine and establishing sanitation system in Japan. ${ }^{10}$

In the same vein, the scholarship portrayed a well-settled, symbiotic relationship between the state and the science community in modern history. While there was a long history of Western science in Japan, James Bartholomew argues, active state sponsorship to cultivate "modern" science in Japan began with the Meiji Restoration in 1868 . $^{11}$ The state encour-

9 Naimushō (Home Ministry), Naimushō Gojūnen Shi (The Fifty Years History of the Home Ministry) (Tokyo: 1923), preface.

10 Naimushō Eiseikyoku (Bureau of Public Hygiene, Home Ministry), Ishi Gōnen Shi (The Fifth Years' History of Medical System) (Tokyo: 1925).

11 James Bartholomew, The Formation of Science in Japan (New Haven: Yale University Press, 1989). 
aged students to study science and medicine abroad and subsidized the establishment of the institutions of higher education and laboratories. Western science was considered modern, and this "modern" science was a currency of civilization. In turn, the science community provided the knowledge that the Japanese empire could use as a colonizing justification and for its governing tools. ${ }^{12}$ As some Japanese scientists and their works gained international reputation, Hiromi Mizuno observes, they further supported the claim of Japanese national superiority, modernity and civilization. ${ }^{13}$ Likewise, while scholars debate about the extent to which the scientific pursuit was free from government surveillance, they generally agree on the stable, reciprocal character of the state-science relationship.

Given these, the 1918 Spanish Influenza was an exceptional event that challenged the claimed harmony within the structure of the state. ${ }^{14}$ When

12 For the use of medical science in colonial administration, see Nitobe Inazō, The Advancement of Medical Science and Colonial Development (1918); among secondary literature, for Korea, see Shin Kyu Hwan, "Unexpected Success: The Spread of Manchuria Plague and the Response of Japanese Colonial Rule in Korea, 1910-1911," Korea Journal 49, no. 2 (Summer 2009); for Ezō or Hokkaido, see Brett Walker, "The Early Modern Japanese State and Ainu Vaccinations: Redefining the Body Politics, 1799-1868," Past and Present 163, issue. 1 (May 1999); for Taiwan, see Michael Shiyung Liu, Prescribing Colonization: The Role of Medical Practices and Polices in Japan-Ruled Taiwan (Ann Harbor: Association for Asian Studies, 2009); for Manchuria, see David D. Buck, "Chapter 5: Railway City and National Capital: Two Faces of the Modern Changchun," in Remaking the Chinese City: Modernity and National Identity: 1900 to 1950, ed. Joseph Esherick (Honolulu: University of Hawaii Press, 2001). For the pioneering study on the use of modern science and medicine in colonial pursuit, see David Arnold, Colonizing the Body: State Medicine and Epidemic Disease in Nineteenth-Century India (Berkeley: University of California Press, 1993).

13 Hiromi Mizuno, Science for the Empire: Scientific Nationalism in Modern Japan (Stanford: Stanford University Press, 2008).

14 Previous scholarship on the Spanish Influenza in Japan focused on its etiology and epidemiological impacts or was written in the history of medicine perspective. For the discussion of the flu virus entry from the Siberian Intervention and another ex- 
the flu pandemic hit Japan, it revealed deep gorges within the ministries as well as in the science community. Facing the incomprehensible pandemic, the existing system of infectious disease prevention could neither controll nor contain it. That the flu came in three waves further confused the system. To redress the situation, in 1920, Matsushita Teiji, a former physician and a non-partisan member at the 43rd House of Representatives, proposed to establish a research institute dedicated to the study of the flu. The proposal resulted in forming a special committee with most of its discussants were the members of science community. Yet, over the five meetings the committee had, the committee reduced its mission from building an institute to conducting "a thorough study." In other words, the epidemiologically catastrophic event was rendered into a social problem that merely required a "study" to find solutions. By reconstructing the skirmishes at the committee meetings and the relationships among the discussants, this paper shows how the reduction took place within the

ploring the impact of government censorship under the 9th Prime Minister, Terauchi Masatake (1852-1919) on the public awareness of the ongoing influenza, see Sumiko Otsubo, "Fighting on Two Fronts: Japan's Involvement in the Siberian Intervention and the Spanish Influenza Pandemic of 1918," in The Decade of the Great War: Japan and the Wider War in the 1910s, edited by Tosh Minohara, Tzeki Hon and Evan Dawley (Leiden: Brill, 2014); Sumiko Otsubo, "The influenza pandemic of 1918, Taisho Democracy and freedom of the press during the Siberian Intervention," in Science, Technology in the Modern Japanese Empire, ed. David G. Wittner and Philip C. Brown (London: Routledge, 2016). For the government response to the influenza, see Edwina Palmer and Geoffrey Rice, "Divine Winds versus Devil Wind: Popular Responses to Pandemic Influenza in Japan, 19181920," Japan Forum 4, no. 2 (October 1992). For the comparison of the official responses in Japan and in New Zealand, see Geoffrey Rice and Edwina Palmer, "Pandemic Influenza in Japan and New Zealand, 1918-19: Mortality Patterns and Official Responses," The Journal of Japanese Studies 19, no. 2 (Summer 1993). For a case study on how a country doctor reacted to the flu, see Edwina Palmer and Geoffrey Rice, "Japanese Physician's Response to Pandemic Influenza: Ijiro Gomibuchi and the 'Spanish Influenza' in Yaita-Cho, 1918-1919," Bulletin of the History of Medicine 66, no. 4 (Winter 1992). 
context of the 1920s' party politics and the bureaucratic system managing medical science. Contrary to the façade of completeness, the Japanese state in the story of the Spanish Influenza exhibits a wobbly amalgam of fragmentary party interests and incoherent ministerial authorities.

\section{Earlier Attempts}

Following the earlier inter-ministerial telegraphs, on November 13, 1918, the Bureau of Public Hygiene commissioned the Saiseikai (Society to Assist Livelihood) to formulate the guideline. ${ }^{15}$ The Saiseikai was a philanthropic foundation established in 1911 under the auspices of the Japanese emperor. Although private in its administration, it served the public interest, particularly in helping the poor. The Japanese state during the Meiji period (1868-1912) subscribed to the view of social welfare that placed responsibility for economic survival on the individual and the family. In the 1910s, however, with the influx of socialist thoughts, the bureaucrats making social policy conceded that poverty may also result from reasons beyond individual control and the state should take some responsibility to prevent social disorder. As a compromise, they subsidized the private philanthropic capacity at their disposal. ${ }^{16}$ Now in 1918, that the Bureau of Public Hygiene called in the Saiseikai as the first organization to deal with the pandemic reveals the absence of a clear division between the public and the private. In fact, the commission included unequivocally stately functions, namely the collection of demographic damage data from every prefecture and the analysis of the preventive measures in practice at the moment. The commission shows the heavy

15 Naimushō Eiseikyoku, Ryukōsei Kanbō.

16 Sally Ann Hastings, Neighborhood and Nation in Tokyo, 1905-1937 (Pittsburg: University of Pittsburg Press, 1995), 32-3. For the political implication of the Saiseikai on the emperor-centered polity, see also Sheldon Garon, Molding Japanese Minds: The State in Everyday Life (Princeton: Princeton University, 1998), 49. 
reliance of the state on the goodwill private sector even in the issue potentially of life and death to its subjects.

In January 1919, the Bureau of Public Hygiene came to grasp the severity of the ongoing flu pandemic. Early in the year, the Saiseikai concluded that the commission was too costly a project to afford. As the first order in February, the Bureau asked each prefectural governor to report back the four types of information. They included: the number of flu patients heretofore report, the summary of the preventive measures, the overview of the contagion in the prefecture, and the comparative analysis of the current flu pandemic and the prefecture's experiences during the 1890 Asiatic flu outbreak. On February 5, while waiting for the prefectures to respond, the Bureau published and distributed five million copies of a temporary protocol. The protocol, titled "the Understanding of the Contagious Cold Prevention" stressed five points. ${ }^{17}$ They were:

- In the area where the flu outbreak was reported, avoid any large gatherings of people.

- When having headache or fever, visit the doctors promptly.

- Patients must be hospitalized and will not be permitted to leave the room unless fully recovered.

- Encourage the use of the respiratory protection device, particularly in the household when interacting with the patients or entering the infected environments.

- Encourage people to gargle.

The five points resulted from a mixture of the existing contagious disease prevention system and knowledge of the pneumonic plague that swept Manchuria in 1910 and 1911. With no sufficient data collected, the Bureau could not determine whether the flu outbreak qualified to be a legally defined contagious disease. The medical technicality was im-

17 The Bureau of Public Hygiene, "The understanding of the contagious cold prevention," February 5, 1919. 
portant to decide whether the state could activate the Contagious Disease Prevention Act of 1897 (Law No. 36). As the later debates in 1920 revealed, the bureaucrats in the Bureau considered the possibility of applying the law as the contagion rate spiked. And yet, with no identifiable bacterial agent found, they could not persuade their superiors in the Home Ministry. ${ }^{18}$ Nonetheless, the first three points were coopted from the basic understanding of the contagion in the 1897 Act. The last two points, suggesting the respiratory aspect of the contagion, came from the recent medical discovery in the Great Pneumonic Plague of 1910-1911 in Manchuria. $^{19}$

The following influenza prevention measures, while different in their styles and degrees of scientific explanation, basically reiterated the five points. Except for "respiratory protection device" being changed to "mask," the prevention guidelines in December 1919 and in February 1920 did not have any qualitative differences. If there were any major changes in the guidelines from early 1919, it was the use of posters to propagate the five points. The posters attached to the December 1919 prevention guideline captured five scenes. All of them depicted how the disease could sneak into everyday people's lives. For example, the first one portrayed a woman in kimono worriedly looking at the thermometer that presumably measured the temperature of her husband. Over his shoulders, a small monster with a fan saying "the cold" was approaching. The banner line reads, "If you are feeling unwell, immediately cure it." Another illustrated a mother and two children. Next to the mother is the monster again, and sinister dust flying out of the mother's cough into the air and toward the children's faces. For this one, the banner reads, "The contagious flu spreads like this; do not infect the children." Yet another

18 “流行性感冒症予防法研究機関設置に関する建議案,”第四三回帝国議会会議録 (Minutes of the proceedings in the House of Representatives, the 43rd session), July $22,1920$.

19 William C. Summers, The Great Manchurian Plague of 1910-1911: The Geopolitics of an Epidemic Disease (New Haven: Yale University Press, 2012), 67. 
was placed inside a busy train. A coughing man spreads the sinister dusts from his mouth, and yet everyone else in the train wears masks. The banner says, "You must be afraid of the influenza germ; without a mask, you can't tell your future." 20 The posters in the February 1920 prevention guideline appended few details. Likewise, for the most of 1918 and 1919 when the flu was most virulent, the Bureau of Public Hygiene was unable to provide the people with scientifically proven, effective prevention measures.

\section{The Special Committee}

On July 14, 1920, Matsushita Teiji, a representative from Kagoshima prefecture who was also a professor of medicine at Tokyo Imperial University, proposed to build a new research institute. It would be dedicated to work on the influenza and its preventive measures. The ravages brought by the pandemic, he provided, included 2,405,666 patients and 127,282 casualties. In addition, the lack of effective prevention or emergency protocol for the influenza pandemic caused the central and local governments to spend a large amount of money on the makeshift measures. From November 1918 to May 1919, the central government alone made the unexpected expenditure of 180,559 yen which by 2010 conversion, would cost $\$ 6,722,442$. Like their counterparts aboard, Japanese scientists failed to locate the causative agent or discover the mechanisms of contagion and infection. Yet, the failures, Matsushita argued, were due to the lack of concentrated efforts. Had there been a central research engine as in the case of cholera, they would have already known more about the flu.

Matsushita framed the pandemic as a "social problem" and employed language that would have appealed to his contemporaries. The year of 1920 marked the beginning of "Taisho democracy." In the political do-

20 Naimushō Eiseikyoku, Ryukōsei Kanbō, 158-62. 
main, the early samurai-based politicians and their direct disciples in the army yielded power to those who were party members. The rise of Hara Takeshi, a prominent party politician as the prime minister in 1918 over Terauchi Masatake, a former military general also reflected the switch from "military rule (bundan seiji)" to "cultural rule (bunka seiji)." On the surface, Japanese subjects gained more freedom of speech and activities while in darkness, secret police replaced the military police. Nonetheless, as the country steamrolled rapid and labor-intensive industrialization along with the tolerant political culture and the influx of socialist ideas, labor strikes swirled in the urban centers. With the Election Law reform in 1920 and subsequent universal male suffrage in 1925, the workingclass voice gained ways to reach high politics. Their demands often carried the agendas of social policy reforms, which would require extra efforts, if not restructuring of the government bureaucracies and ministerial administration. While party politicians catered to the working-class interests in exchange of votes, once entered the Diet, they often prioritized their station within the party and tried not to disrupt the relationship between the state ministries and the parties. ${ }^{21}$ The term "social problem" was born in this political culture and often described the dissident issues that the state considered the cause for unrest among the constituency and for potentially upsetting the existing social order. In turn, the term gave a layer of urgency and significance to the issue. In 1920 when Matsushita introduced the Spanish Influenza as a "social problem" more atrocious than the Communists or the partisans, he was politicizing the epidemiological event.

Matsushita also touched on another salient idea at the time in saying that the development of the flu cure through the special research institute would elevate Japan as "the savior of the world." In the 1920s, Japan was keen on standing as an equal partner of Westerners in the international

21 Garon, Molding Japanese Minds, 144-5; Andrew Gordon, Labor and Imperial Democracy in Prewar Japan (Berkeley: University of California Press, 1991), 130-12. 
community. ${ }^{22}$ In fact, Japan fulfill the so-called conditions of most "civilized" Western empires such as the acquisition of colonial territories, the abolition of unequal treaties, and military feats. Japan's advance was disrupting the perceived racial hierarchy, in which the white race presided over the non-whites. The Western empires responded to the advance by disclaiming Japan's civilization. And the response led to the failure of the Japanese delegation's attempt to include the "racial equality clause" in the Covenant of the League of Nations at the 1919 Paris Peace Conference. ${ }^{23}$ Despite the failure, Japan continued making efforts to prove its civilization. Humanitarian causes, closely associated with the colonialist idea of "civilizing missions," appealed to the Japanese government. ${ }^{24}$ As Japan's active participation in the Red Cross societies attested, medical help exhibited both humanitarian spirit and superior medical science. ${ }^{25}$ As such, Matsushita's call for Japan's becoming "the savior of the world" incited the Japanese politicians who were eager to put Japan on the same page as other Western nations.

The potential outcomes of Matsushita's proposal, tackling the "social

22 Peter Duus, Party Rivalry and Political Change in Taisho Japan (Cambridge, Harvard University Press, 1968), 5.

23 Naoko Shimazu, Japan, Race and Equality (London: Routledge, 1998), 115.

24 Gregory De Pies, "Humanitarian Empire: The Red Cross in Japan, 1877-1945" (PhD diss., University of California, San Diego, 2013), 3.

25 Prewar Japan had the large membership of the Red Cross second only to the United States. During World War I, the Japan Red Cross sent medical team to European battlefronts and military hospitals in Russia, France and Britain. The team consisted of 132 relief squads and two hospital ships with a total of 4538 medical workers. On the other hand, in 1919 when the inclusion of the racial equality clause failed, Japan actively joined the League of Red Cross Societies, an associated but different entity from the Red Cross. The League was established by five nations: the US, Japan, the UK, France, and Italy and aimed at international cooperation in medical science and global hygiene. For more information on the Red Cross Society of Japan, see Sho Konishi, "The Emergence of an International Humanitarian Organization in Japan: The Tokugawa Origins of the Japanese Red Cross," The American Historical Review 119, no. 4 (October 2014). 
problem" of Spanish Influenza while proclaiming Japan's name, appealed to the politicians. ${ }^{26}$ On July 14, 1920, the "committee discussing the proposal to establish an institution researching the influenza prevention (hereafter 'the committee')" was formed, and during the month, the special committee met five times, leaving three sets of meeting minutes available. ${ }^{27}$ Except for the last meeting, the discussants consisted of eleven people. Beside the four government bureaucrats, the rest were all elected representatives with partisan associations. The discussants and their profile were as follow:

\begin{tabular}{|c|c|}
\hline & Profile as of 1920 \\
\hline Ushio Shigenosuke & The Chief of the Bureau of Public Hygiene (Home Ministry) \\
\hline Matsuura Shigejiro & $\begin{array}{l}\text { The Chief of the Bureau of Special Schools (Ministry of Educa- } \\
\text { tion) }\end{array}$ \\
\hline Ishihara Kikutaro & $\begin{array}{l}\text { The Scholar-Engineer at the Institute of Contagious Disease; } \\
\text { The Professor of Medicine at Tokyo Imperial University }\end{array}$ \\
\hline Uchino Senichi & Quarantine Officer; the Scholar-Engineer at the Home Ministry \\
\hline $\begin{array}{l}\text { Ishikawa Genzō } \\
\text { (Committee Chairman) }\end{array}$ & Seiyūkai \\
\hline Yamada Eishun & $\begin{array}{l}\text { Seiyūkai; Studied Regenerative Biology at Tokyo Special School } \\
\text { of Medicine; } \\
\text { The President of Gifu Prefecture Doctors Association; } \\
\text { The Board Member of Gifu Health Insurance Company }\end{array}$ \\
\hline Iwasaki Somosuke & $\begin{array}{l}\text { Seiyūkai; Studied Regenerative Biology at Tokyo Special School } \\
\text { of Medicine; } \\
\text { A Former Military Doctor at Sino-Japanese \& Russo-Japanese } \\
\text { Wars }\end{array}$ \\
\hline Akimoto Kishichi & Seiyūkai; A Member of the Police Epidemic Prevention Unit \\
\hline $\begin{array}{l}\text { Nishimura Isuke } \\
\text { (Only in the last } \\
\text { meeting) }\end{array}$ & $\begin{array}{l}\text { Seiyūkai; } \\
\text { Studied Law at Tokyo Imperial University }\end{array}$ \\
\hline
\end{tabular}

26 第四三回帝国議会会議録 (Minutes of the proceedings in the House of Representatives, the 43rd session), July 14, 1920.

27 “流行性感冒症予防法研究機関設置に関する建議案,”第四三回帝国議会会議録 (Minutes of the proceedings in the House of Representatives, the 43rd session), July 22,1920 . 


\begin{tabular}{l|l}
\hline $\begin{array}{l}\text { Matsushita Teiji } \\
\text { (Proposal }\end{array}$ & $\begin{array}{l}\text { No Party; A Member of Koshin Club; } \\
\text { Studied Medicine at the Fifth High School; } \\
\text { Acquired Ph.D. at University of Freiburg in Sanitary Science and } \\
\text { Bacteriology }\end{array}$ \\
\hline Chūma Okimaru & Kenseikai; Studied Medicine at the Fifth High School \\
\hline Kagawa Yasutada & $\begin{array}{l}\text { Kenseikai; Studied Medicine at the Fourth High School; } \\
\text { A Member of Toyama Prefecture Doctors Association }\end{array}$ \\
\hline Kondo Tatsuji & $\begin{array}{l}\text { Rikken Kokumintō (later Seiyūkai); } \\
\text { Studied German Law at Tokyo Imperial University } \\
\text { A Beneficiary of the Tokyo Illness Rehabilitation Center }\end{array}$ \\
\hline
\end{tabular}

As the profile chart illustrates, the majority of the committee members studied medicine at various levels or worked at a government office that required a degree of medical and epidemiological knowledge. The exceptions were both Seiyūkai members, Ishikawa Genzō, the committee chairman and Nishimura Isuke who only joined for the last meeting of the committee. Later it was the voice of these two that changed the outcome of the committee meetings.

\section{Behind Closed Doors}

When Mastushita Teiji gave the opening speech on July 22, 1920, he must have thought the discussion would go smoothly. He reiterated the points he brought out during the Diet meeting a week prior and this time, added how grateful he was to be with those in the government interested in saving the people and elevating the status of medical science. His first remark ended, "Now, shall we discuss the details of the research institute?"

To Matsushita's dismay, his proposal was never realized. Over the course of the committee meetings, the proposal to establish a research institute for the Spanish Influenza was reduced to merely a proposal to conduct a thorough study of the flu. There were three major points of contention, and different discussants had different opinions about them. These points included (1) was a new research institute necessary? (2) what 
went wrong in the existing system? and (3) who was or were responsible for the malfunction of the system? The inter-ministerial and interpersonal relationships muddled all these points and eventually changed the original proposal.

Ishihara Kikutaro and Ushio Shigenosuke were the first to cast doubt on the necessity of an institute. As a scholar-engineer at the Institute of Contagious Disease and a professor of medicine at Tokyo Imperial University, Ishihara posited "what is needed is not a new institute but more funding for concentrated research that is already going on." Ushio, the Chief of the Bureau of Public Hygiene agreed with Ishihara. Ushio's agreement was also to defend his own organization. In 1914, the formerly private Institute of Contagious Disease was merged into the Faculty of Medicine at Tokyo Imperial University. While the scholar-engineers at the Institute became government servants and could conduct their private research without much financial concerns, in the time of public health emergency, they had to follow the command of the Bureau of Public Hygiene.

Taken aback, Matsushita laid out a list of problems he observed during the flu outbreak. First, the existing system was too slow to respond. The Bureau of Public Hygiene commissioned the Institute of Contagious Disease, and yet, the scholar-engineers at the Institute were not so keen on spending their time and resources on the public cause since such a cause would not bring them personal prestige. Also, the Institute focused on the eight legally defined contagious diseases under the 1897 Contagious Disease Prevention Act and was barely equipped to deal with a new disease. ${ }^{28}$ As a result, Matsushita argued, the Institute produced a rather poor-quality vaccine. He also problematized the activity of the hygiene police under the Bureau of Public Hygiene. The presence of police going around the town and invading private households to uphold inspections

28 The Contagious Disease Act of 1897 specified its application for the 8 legally defined contagious diseases including cholera, dysentery, typhoid, smallpox (variola), epidemic typhus, scarlet fever, diphtheria, and plague. 
generating fear among the people who in turn, did not report even if they had the symptoms of the flu. Then, the police noticed the outbreak only when the flu already spread. Likewise, he stressed that "should the special institute focus on the flu and prepare its own civil means of vaccine distribution, it would solve all these problems."

With Matsushita's full-blown rebuttal, Ushio tried to evade responsibility for the Bureau and toss the ball to Ishihara. When Ushio criticized the Institute for "the tardiness of effective results," Matsuura Shigejiro, the Chief of the Bureau of Special School under the Ministry of Education added a few comments. Matsuura was unmistakably sarcastic, saying "Today, even the son of a poor farmer can become a successful businessman with dedication and hard work. Should the Institute, as its researchers claim, have spent all its resources on the preventive measure, how could it not yet have come?" Matsuura, however, pointed at the Bureau of Public Hygiene that "the ultimate responsibility is on the Bureau as it entrusted the lives of the emperor's subjects on the incompetent bunch."

Matsuura's hostility toward the Bureau of Public Hygiene resulted from the ongoing struggle between the Ministry of Education and the Home Ministry over the authority to administer the license exam for medical practitioners. The contention was an exception. For the most part of their histories, the Home Ministry and the Ministry of Education shared a pool of leading career bureaucrats. In fact, the two most prominent ministries were "the successful bureaucrat's basin," and the bureaucrats held offices interchangeably. ${ }^{29}$ For example, Ushio Shigenosuke from the Home Ministry in 1920 became the minister of the Ministry of Education in 1931. Matsuura, although criticizing the Bureau of Public Hygiene in the meeting, had begun his bureaucrat career at the Home Ministry in 1898.

The ministerial contention arose in 1919 when the University Ordinance further blurred the line between clinicians and doctors who were

29 Bernard S. Silberman, "Bureaucratic Development and Bureaucratization: The Case of Japan,” Social Science History 2, no. 4 (Summer 1978): 387. 
respectively under the purview of the Bureau of Special Schools and the Bureau of Public Hygiene. Granted, from the beginning, the ministerial jurisdiction over scientific research was ambiguous. For instance, the Education Ordinance in 1898 authorized the Ministry of Education to "supervise and encourage sciences and arts" while some of the advanced medical research occurred within the Bureau of Public Hygiene. ${ }^{30}$ As for the license to work as a medical practitioner, under the Regulations of Doctors, the Home Ministry primarily regulated and held authority over "the doctors" who either graduated from the Faculty of Medicine at Tokyo Imperial University or passed the official doctor's exam. Yet, the Ministry of Education had the Bureau of Special Schools that oversaw the vocational schools and managed the certification of other medical practitioners including clinicians, nurses, and midwives. The potentially overlapping jurisdiction was not a problem in the earlier days when the number of medical practitioners was so small that in the market for medical profession, demand exceeded supply. However, by the late 1910s, the number increased to the point where the clinicians from vocational schools and the doctors from universities had to compete for their income. The university graduates often assaulted the vocational school graduates for the clinicians were only "supplementary to the true doctors contributing to the nation's scientific development" whereas the clinicians derailed the doctors for "being snobby" and not catering to the actual patients. ${ }^{31}$ In 1919, the University Ordinance elevated the status of some vocational schools to that of university and granted the graduates with the prestige on par with that of university graduates. The Bureau of Public Hygiene strongly opposed the law and in 1920 during the discussion for the Spanish Influenza research institute, was forcing the Home Ministry to pressure the Ministry of Education to annul the effect of the legisla-

30 Bartholomew, The Formation of Science in Japan, 204.

31 Alexander Bay, Beriberi in Modern Japan: The Making of a National Disease (Rochester: University of Rochester Press, 2012), 37-9. 
tion. $^{32}$

Before Ushio from the Bureau of Public Hygiene jumped to its defense, Ishihara contended for the position of the Institute and pointed his finger at the Bureau for being "not fully supportive." To Matsuura's earlier analogy between the self-made man and research result, he replied that "scientific discovery is different from the economic relation where input is always proportional to outcome." In turn, he faced Ushio and blamed the Bureau of "dividing the research funding and allocated a significant amount to the Kitasato Institute."

After 1914, the Kitasato Institute had become an aggressive rival with the Institute of Contagious Disease and vied over research projects, funding, and reputation. The Kitasato Institute was a private research institute, named after its founder, Kitasato Shibasaburo who was also the founder of the Institute of Contagious Disease. As a renowned scientist, Kitasato studied under the world-famous Robert Koch in Germany and discovered a number of the chronic disease bacterium including the Pfeiffer bacillus. Upon coming back to Japan, he wanted to build a research environment "free from any political influence," and Fukuzawa Yukichi, perhaps the most prominent figure in Meiji Japan, supported his aim and helped establishing the Institute of Contagious Disease in 1892. However, while he remained unchallenged in the field of science, his authoritative presence in the science community, on top of his nonconformist, apolitical stance, ticked off some scientists outside "the Kitasato faction." The Faculty of Medicine at Tokyo Imperial University had a few of those displeased with Kitasato. In fact, Ishihara himself had an adverse relationship with Kitasato after Kitasato refused to work with him. ${ }^{33}$ As such, those at Tokyo

32 第四三回帝国議会会議録 (Minutes of the proceedings in the House of Representatives, the 43rd session) July 4, 1920 (Tokyo). The issue of ministerial authority over the medical practitioners was discussed independent of the Spanish Influenza case.

33 Ishihara Kikutaro in Kitasato Shibasaburo's biography. Takano Rokuto, Kitasato Shibasaburo: Collection of Contemporary Biography, Vol. 2 (Tokyo: Popura, 1959). 
Imperial University pushed the Ministry of Education to nationalize the Institute of Contagious Disease as it would serve the public interest better with government support. Despite Kitasato's opposition, in 1914, the merger with Tokyo Imperial University took place. Enraged Kitasato declined the position of Chief researcher-engineer at the Institute, took his pupil-researchers, and established the Kitasato Institute. In 1918, when the Spanish Influenza casualty became increasingly severe, the Bureau of Public Hygiene, while officially commissioned the Institute of Contagious Disease, also asked for help to the Kitasato Institute for effective vaccination. Ishihara's criticism on the Bureau was about this.

When Ishihara brought out the Kitasato Institute, Uchino Senichi, the quarantine officer and a researcher-engineer at the Home Ministry, came forward to rail against the inefficiency of the Institute and the Bureau. Since the quarantine office followed the Home Ministry except under martial law, it is difficult to understand why Uchino reprimanded his own command. While there is no direct evidence from Uchino, I suppose his friendship with Kitasato might have prompted him to speak in his defense. It was a bureaucratic custom in prewar Japan that when resigning from public office, the bureaucrat had to submit a health certificate proving that he was ill-suited for the position. When Kitasato retired, he refused to be diagnosed by anyone in the government but Uchino as he did not trust those working "under the auspices of corrupt institutions." ${ }^{4}$ In 1920, it might have been the case that Uchino was irritated by Ishihara's mention and potential criticism on his friend, Kitasato.

Nonetheless, from the second committee meeting onwards, the mention of the Kitasato Institute triggered the opposition party politicians in the committee to speak against the bureaucracy in general for the poor response during the 1918 flu pandemic. Chuma Okimaru from the Kenseikai castigated Ishihara that during the emergency situation, the Institute of Contagious Disease was the only one officially commissioned and yet

34 Takano Rokuto, Kitasato Shibasaburo: Collection of Contemporary Biography, Vol. 3 (Tokyo: Popura, 1959), 115. 
"more or less missing." Kondo Tatsuji from the Rikken Kokuminto demanded a comprehensive comparison between the vaccines produced by the Institute of Contagious Disease and those by the Kitasato Institute.

Ushio, the Chief of the Bureau of Public Hygiene gave a technical and yet, roundabout answer to the comparative effect of the vaccines. He explained that "as for which kind of vaccine is better, it depends on the patient's condition and the degree of the progress of illness." As if the Bureau wanted to mend the relationship with the Institute and Tokyo University, he added that the vaccine produced by the Kitasato Institute contained only the diluted Pfeiffer bacillus whereas one from the Institute of Contagious Disease had Pfeiffer bacillus and pneumonia bacillus, implying the latter can cover a wider range of symptoms.

The presence of the Pfeiffer bacillus in both vaccines, however, ironically attested to the prominence of Kitasato Shibasaburo in Japanese epidemiology and public health policy. In 1892, working at Robert Koch's lab in Berlin, Kitasato was in a partnership with German bacteriologist Richard Friedrich Pfeiffer. They cultivated a new kind of bacterium that Kitasato claimed to be the causal agent of contagious influenza. Pfeiffer's 1893 report backed this claim and located the Pfeiffer Bacillus or haemophilus influenzae. In 1918 when the Spanish Influenza swept the world, despite some strong counter-evidences from Rockefeller scientists Peter Kosciuko Olitsky and Fredrick Gates, the science community banked on Kitasato and Pfeiffer's laboratory research. ${ }^{35}$ And a number of nations implemented the emergency public health measures based on the association of the Pfeiffer bacillus with the influenza outbreak. ${ }^{36}$

35 Jeffery K. Taubenberger, Johan V. Hultin and David M. Morens, "Discovery and Characterization of the 1918 Pandemic Influenza Virus in Historical Context," Antiviral Therapy 12, no. 4 Part B (2007).

36 For this association in the United States, see Alfred Crosby, America's Forgotten Pandemic: The Influenza of 1918 (Cambridge: Cambridge University Press, 1989). For the case in Canada, see Mark Osborne Humphries, The Last Plague: Spanish Influenza and the Politics of Public Health in Canada (Toronto: University of Toronto Press, 2013). For various comparative cases, see David Killingray and How- 
In 1918 Japan, the authority of Kitasato's claim on the Pfeiffer bacillus and the influenza vetoed a series of clinical results that could not verify the causal link between the bacteria and the illness. In fact, Kitasato's activity during the 1910-1911 Manchurian Plague further buttressed his scientific authority. ${ }^{37}$ In 1920, a physician-doctor, Sasaki Shuichi reported to Japana Centra Revuo Medicina that the Pfieffer bacillus was found in only $37 \%$ of sample patient bodies he dissected. Despite his own finding, Sasaki concluded that "[the low appearance of the bacteria] would have been resulted from experimental mistakes, [which] is not uncommon." ${ }^{38}$ Likewise, given the establishment of Kitasato and later his pupils in the international science community, ${ }^{39}$ Japanese scientists and the public health bureaucrats, whether they liked Kitasato personally or not, consulted with Kitasato's research on the influenza bacteria. In 1918-1919, that the vaccines produced under government funding all contained the Pfeiffer Bacillus proved that those in the Institute of Contagious Disease who were in opposition with Kitasato, still submitted to the authority of his claim.

ard Philips, eds., The Spanish Influenza Pandemic of 1918-1919: New Perspective (New York: Routledge, 2011).

37 Summers, The Great Manchurian Plague of 1910-1911, 7·88. He visited Manchuria for the inspection of the South Manchurian Railway. His remark on the Manchurian conditions was published in English. He said the control of the disease is an "easy thing to accomplish from the scientific point of view." His "sharing of wisdom" in Manchuria gave him an air of trust.

38 Sasaki Shuichi, “流行性感冒/原因及ビ療法二就テ (On the Cause of the Influenza)," Japana Centra Revuo Medicina 17, no. 20 (April 1920).

39 For example, American surgeon Louis Livingston Seaman wrote The Real Triumph of Japan: the Conquest of Silent Foe after attending the military medic campaigns in the Russo-Japanese War in 1905. The book highlighted the Japanese military doctors' anti-bacterial regimen based on the theory that the identifiable bacteria or germs cause the disease. Seaman also listed the names of the "Kitasato faction" who "saved the humanity from the threat of the silent foe [the bacteria]." For further sources, see Louis Livingston Seaman, The Real Triumph of Japan: The Conquest of the Silent Foe (New York: D. Appleton and Company, 1908). 
On July 24, 1920, the last committee meeting brought the "social problem" of the Spanish Influenza to the realm of party politics. Kagawa Yasutada from the Kenseikai inquired, "that the existing organizations failed to effectively deal with the flu situation. I wonder how such a system and people could stay in position for so long." Kondo Tatsuji also spoke against the Bureau of Public Hygiene and the Institute of Contagious Disease. He suggested that the Home Ministry must have sided with "the incompetent one" simply because people at the Institute and the university supported its establishment. Speaking on behalf of his constituency, Yamaguchi prefecture, Kondo criticized that 38 people died of bacterial overdose due to the poor-quality vaccine. Chuuma Okimaru, also from the Kenseikai, added that "the politicians in the government who let the Ministry misuse the tax money" should also take the responsibility for the tragedy. All these politicians tilted the direction of criticism from Ishihara and Ushio to the Seiyukai, the dominant party with legislative power.

The Seiyukai politicians who had remained mostly quiet, began speaking in their defense and questioned the integrity of Matsushita Teiji, the proposal initiator. Yamada Eishun pointed at Matsushita's membership to the Koshin Club to dispute his claim that the civilian damages motivated him to adduce the proposal. The Koshin Club was a group of elected politicians characterized with their industrial participation and weak political cohesion. Until the Club dissolved in 1924, they tended to cast their votes based on their economic interests, regardless of party politics. Yamada's attack, while suspecting essentially everyone who was not partisan, implied that Matsushita would covet private profit from the new research institute for the flu. In fact, the idea that public health crisis could mean a big money for those in medicine was not unknown. The profitability of medical enterprise was particularly true in the late 1910s when Japanese businesspeople got their hands on the German patents now revoked in Japan at the dawn of World War I. ${ }^{40}$ Many of the committee discussants

40 The period 1902 to 1918 marked the first major growth in the Japanese industrial patent system. From 1918 to 1920, in particular, the number of domestic patent ap- 
held managerial positions in the medical and pharmaceutical businesses. For example, Kagawa Yasutada of the Kenseikai was a board member at Tateyama pharmaceuticals, and Yamada himself was the chair of the Gifu prefecture health insurance company and of Tuberculosis Vaccine Production. Akimoto Kishichi, the Seiyukai politician who joined the last committee meeting without a medical degree, also sat at the board room of Shikisho Koshin Company, manufacturing and distributing pharmaceutical products to the military. ${ }^{41}$

Other Seiyukai members supported Yamada's remark and changed the very topic of the discussion. Yamada continued that building a separate institute for the influenza would be not only costly but also "disruptive of the order." When Iwasaki Sonosuke, also from the Seiyukai, seconded him, Yamada suggested changing the issue from building an institute to conducting "a thorough study of the prevention of the influenza." Matsushita Teiji and Kondo Tatsuji expressed strong opposition. Kondo suspected that should the proposal change, then the government would simply spend more money on the "incompetent" researchers at the Institute of Contagious Disease and those at Tokyo Imperial University who were "brownnosing" the Home Ministry and "corrupt" politicians. Despite the resistance, all the Seiyukai discussants supported Yamada's suggestion.

Only for the last meeting, as Nishimura Isuke of the Seiyukai joined, the committee composition changed to reflect the Seiyukai majority in the regular Diet session. Just a couple months before, on May 10, 1920, the 14th House of Representatives election took place. It was the first election that the electoral law reform in 1919 had an effect. The reform lowered the tax qualification from 10 Yen to 3 Yen, allowing suffrage to almost

plications related to technology, as German patents were annulled, rapidly increased. For further the graphic analysis of the pattern of Japanese patent application, see Pierre-Yves Donzé, "The Beginnings of the Japanese Medical Instruments Industry and the Adaptation of Western Medicine to Japan, 1880-1937," Australian Economic History Review 56, issue 3 (November 2016).

41 Taisho Jinmei Jiten (Taisho Biographical Dictionary) (Tokyo: Shimposha, 1918). 
every employed man over 25 years old. The number of votes for the $14^{\text {th }}$ election exceeded 3 million and raised the flag for "Taisho democracy." In effect, historians argued, the expansion of suffrage was a means for the state to prevent more serious social disorder in a society already marked with civilian protests and civil rights movements. The Kenseikai, the first opposition party, promoted political democratization, social reforms, and remedial legislation "to inoculate the country against future popular unrest." Nonetheless, as Duus clarifies, the electoral law reform could not change the Seiyukai dominance in the government. Along with the expansion of suffrage, the reform also gerrymandered the districts to Seiyukai's advantages. ${ }^{42}$ The partisan composition of the Spanish Influenza committee's last meeting showed the exact same composition as the $43^{\text {rd }}$ Diet.
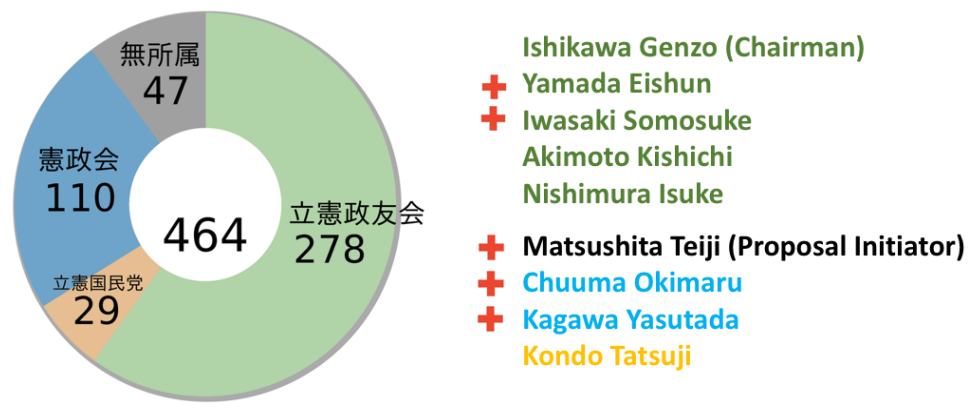

When Yamada suggested changing the proposal, with the Seiyukai majority, Ishikawa Genzo, the chairman of the committee called for a vote. As the four bureaucrats "did not represent the voice of the people," they did not have votes. The result was a 4:4 draw. All the Seiyukai members voted for the proposal change from "the establishment of a research institute" to "conducting a thorough study of the prevention of the influenza," whereas all the non-Seiyukai discussants voted no. Because the vote was a draw, the chairman had the final word: "since no single stance had a ma-

42 Duus, Party Rivalry and Political Change in Taisho Japan, 135-7. 
jority vote, under the authority of the committee chairman, [he] would like to approve Yamada's suggestion."

On July 20, 1920, at the Diet, Ishikawa presented the conclusion of the committee meetings. The committee "deemed it more effective and feasible to conduct a thorough study of the prevention of the influenza" than to build a new research institute. In 1921, the Bureau of Public Hygiene published a book, The Contagious Cold: The Documentation of the Pandemic Spanish Influenza. The book consisted of seven chapters and an appendix. It listed the statistics of the flu patients and mortality rates, the comparison of the damage conditions between Japan and other countries, and the prefectural responses to the pandemic from 1919 to early 1920 . The preface explained that the book was for any bureaucrats or medical practitioners to prepare for a future influenza pandemic. ${ }^{43}$ However, unlike Matsushita's concern and perhaps expectation, the influenza pandemic did not last nor return. More importantly, in 1933, it was discovered that a virus, not bacteria, causes influenza. And with that, the book was never used for its claimed purpose.

\section{Conclusion}

Scholars, while debating the implication of social changes in the Japanese Empire, generally agree on the centrality of the Japanese government to implement those changes. Central to the argument is the perceived stability and structural completeness of the state. The establishment of the government and the relationships among the bureaucracy, the legislature, and the science community all conveyed a formation of the modern state with no cacophony. Yet, in 1918 when the Spanish Influenza swept Japan, the state quickly realized that the existing system of public health could not cope with it. The Bureau of Public Hygiene relied on the private sectors but proved to be ineffective against the flu pandemic that even the

43 Naimushō Eiseikyoku, Ryukōsei Kanbō. 
best medical science at the time could not comprehend.

In 1920, the disease of the Spanish Influenza, as Charles Rosenberg observed, went through a process of different framing. ${ }^{44}$ With the different frames followed the different degrees of felt seriousness and responses. As the pandemic continued, Matsushita Teiji, a newly elected politician and also a doctor, proposed to build a research institute dedicated to the flu. He rendered the Spanish Influenza a "social problem" to carry the political currency the phrase had in the 1920s. He successfully persuaded the general Diet, which then formed a special committee, consisting of ten (later, eleven) people from the different parts of the government. However, over the course of the 1920's meetings, the Seiyukai politicians, in opposition to the non-Seiyukai politicians, reduced the "social problem" to an issue that needed some study. The process of reduction reveals the inter-ministerial skirmishes and the conflicts among different committee discussants. I suggest that the discord behind the Diet door in 1920 was far from being an exception. While the centrality of the government to the historical changes may not be challenged, "the government" consisted of multiple, heterogeneous, and sometimes-competing interests and the constantly changing relationships among the members.

\section{References}

1. Arnold, David. Colonizing the Body: State Medicine and Epidemic Disease in Nineteenth-Century India. Berkeley: University of California Press, 1993.

2. Bartholomew, James. The Formation of Science in Japan. New Haven: Yale University Press, 1989.

44 Charles Rosenberg and Janet Golden, eds., Framing Disease: Studies in Cultural History (Brunswick: Rutgers University Press, 1992), 3. Rosenberg writes, "in some ways, disease does not exist until we have agreed that it does, by perceiving, naming, and responding to it." 
3. Bay, Alexander. Beriberi in Modern Japan: The Making of a National Disease. Rochester: University of Rochester Press, 2012.

4. Buck, David D. "Chapter 5: Railway City and National Capital: Two Faces of the Modern Changchun." In Remaking the Chinese City: Modernity and National Identity: 1900 to 1950, edited by Joseph Esherick. Honolulu: University of Hawaii Press, 2001.

5. Crosby, Alfred. America's Forgotten Pandemic: The Influenza of 1918. Cambridge: Cambridge University Press, 1989.

6. De Pies, Gregory. "Humanitarian Empire: The Red Cross in Japan, 1877-1945." PhD diss., University of California, San Diego, 2013.

7. Donzé, Pierre-Yves. "The Beginnings of the Japanese Medical Instruments Industry and the Adaptation of Western Medicine to Japan, 1880-1937." Australian Economic History Review 56, issue 3 (November 2016): 272-91.

8. Duus, Peter. Party Rivalry and Political Change in Taisho Japan. Cambridge. Harvard University Press, 1968.

9. Epps, Heather L. "Influenza: exposing the true killer." The Journal of Experimental Medicine 203, no. 4 (April 2006): 803.

10. Garon, Sheldon. The State and Labor in Modern Japan. Berkeley: University of California Press, 1987.

11. Garon, Sheldon. Molding Japanese Minds: The State in Everyday Life. Princeton: Princeton University Press, 1998.

12. Gordon, Andrew. Labor and Imperial Democracy in Prewar Japan. Berkeley: University of California Press, 1991.

13. Hastings, Sally Ann. Neighborhood and Nation in Tokyo, 1905-1937. Pittsburg: University of Pittsburg Press, 1995.

14. Hsieh, Ying-Hen. "Excess Deaths and Immunoprotection during 1918-1920 Influenza Pandemic, Taiwan.” Emerging Infectious Diseases 15, no. 10 (October 2009): 1617-9.

15. Humphries, Mark Osborne. The Last Plague: Spanish Influenza and the Politics of Public Health in Canada. Toronto: University of Toronto Press, 2013.

16. Johnson, Chalmers. MITI and the Japanese Miracle: The Growth of 
Industrial Policy: 1925-1975. Stanford: Stanford University Press, 1982.

17. Killingray, David and Howard Philips. The Spanish Influenza Pandemic of 1918-1919. New York: Routledge, 2003.

18. Kim, Taek-joong. “1918nyŏn Tokkamgwa Chosŏnch'ongdokpu Pangyŏkchŏngch'aek (The 1918 Influenza Pandemic and Japanese Government-General of Korea's Preventive Measures against Epidemics)." Inmun Nonchong 74, no. 1 (February 2017): 163-214.

19. Konishi, Sho. "The Emergence of an International Humanitarian Organization in Japan: The Tokugawa Origins of the Japanese Red Cross." The American Historical Review 119, no. 4 (October 2014): 1129-53.

20. Mizuno, Hiromi. Science for the Empire: Scientific Nationalism in Modern Japan. Stanford: Stanford University Press, 2008.

21. Liu, Michael Shiyung. Prescribing Colonization: The Role of Medical Practices and Policies in Japan-ruled Taiwan 1895-1945. Ann Arbor: Association for Asian Studies, 2009.

22. Otsubo, Sumiko. "Fighting on Two Fronts: Japan's Involvement in the Siberian Intervention and the Spanish Influenza Pandemic of 1918." In The Decade of the Great War: Japan and the Wider War in the 1910s, edited by Tosh Minohara, Tze-ki Hon and Evan Dawley. Leiden: Brill, 2014.

23. Otsubo, Sumiko. "The influenza pandemic of 1918, Taisho Democracy and freedom of the press during the Siberian Intervention." In Science, Technology in the Modern Japanese Empire, edited by David G. Wittner and Philip C. Brown. London: Routledge, 2016.

24. Palmer, Edwina and Geoffrey Rice. "Divine Winds versus Devil Wind: Popular Responses to Pandemic Influenza in Japan, 19181920.” Japan Forum 4, no. 2 (October 1992): 317-28.

25. Palmer, Edwina and Geoffrey Rice. "Japanese Physician's Response to Pandemic Influenza: Ijiro Gomibuchi and the 'Spanish Influenza' in Yaita-Cho, 1918-1919." Bulletin of the History of Medicine 66, no. 4 (Winter 1992). 
26. Rice, Geoffrey and Edwina Palmer. "Pandemic Influenza in Japan and New Zealand, 1918-19: Mortality Patterns and Official Responses." The Journal of Japanese Studies 19, no. 2 (Summer 1993): 389-420.

27. Richard, S. A., N. Sugaya, L. Simonsen, M. A. Miller and C. Viboud. "A Comparative Study of the 1918-1920 Influenza pandemic in Japan, USA and UK: mortality impact and implications for pandemic planning." Epidemiology \& Infection 137, issue 8 (August 2009): 1062-72.

28. Rosenberg, Charles and Janet Golden. eds. Framing Disease: Studies in Cultural History. Brunswick: Rutgers University Press, 1992.

29. Silberman, Bernard S. "Bureaucratic Development and Bureaucratization: The Case of Japan." Social Science History 2, no. 4 (Summer 1978): 385-98.

30. Shimazu, Naoko. Japan, Race and Equality: The Racial Equality Proposal of 1919. London: Routledge, 1998.

31. Shin, Kyu Hwan. "Unexpected Success: The Spread of Manchuria Plague and the Response of Japanese Colonial Rule in Korea, 19101911." Korea Journal 49, no. 2 (Summer 2009): 165-82.

32. Summers, William. The Great Manchurian Plague of 1910-1911: The Geopolitics of an Epidemic Disease. New Haven: Yale University Press, 2012.

33. Taubenberger, Jeffery K., Johan V. Hultin and David M. Morens. "Discovery and Characterization of the 1918 Pandemic Influenza Virus in Historical Context." Antiviral Therapy 12, no. 4 Part B (2007): 581-91.

34. Walker, Brett. "The Early Modern Japanese State and Ainu Vaccinations: Redefining the Body Politics, 1799-1868." Past and Present 163, issue. 1 (May 1999): 121-60. 


\section{"A Thorough Study of the Spanish Influenza": How Jap- anese Party Politics and Ministerial Conflicts Reduced the Pandemic}

Juhee Kang

When the Spanish Influenza hit Japan from 1918 to 1920, it revealed deep cleavages within the governmental ministries as well as in the scientific community. It posed an incomprehensible problem while causing massive demographic damage that the existing system of emergency protocols could contain. To redress the situation, in 1920, Matsushita Teiji, a former physician and a non-partisan member at the 43rd House of Representatives, proposed to establish a research institute dedicated to the study of the flu. The proposal resulted in the formation of a special committee with most of its discussants prominent members of the scientific community. Yet, over the five meetings the committee held, the committee reduced its mission from building an institute to conducting "a thorough study." The catastrophe, comparable to a natural disaster worsened by the lack of a preventive system, was rendered into a social problem that merely required a "study" to find solutions. By reconstructing the skirmishes at the committee meetings and the relationships among the discussants, this paper shows how the reduction took place within the context of 1920s' party politics and the bureaucratic system managing medical science. Contrary to the façade of structural stability that some historians and itself promoted, the Japanese state in the story of the Spanish Influenza exhibits a wobbly amalgam of fragmentary party interests and incoherent ministerial authorities.

Keywords: Japanese Empire, Spanish Influenza, Infectious Disease Prevention, Party Politics, Medical Inspection 


\section{〈국문초록〉}

\section{스페인독감의 심층조사: 1920년대 일본의 의회 정치와 전염병}

강주희 (하버드대 동아시아언어문명학과 박사과정)

본 연구는 일본제국 정부가 1918년에서 1920년까지 유행했던 스페인독감을 어 떻게 이해하고 이에 대처하려 하였는가를 통해 1920년대 일본제국 정부의 구조적 모순과 정당, 부서 간 불협화음을 보여준다. 독감바이러스가 발견되지 않았던 1920년 당시 스페인독감은 전세계적으로 예방과 치료가 불가능한 전염병이었다. 특히 독감 증상 중 하나였던 '면역계 과잉반응 (cytokine syndrome)'은 건강한 면 역계를 가지고 있던 20 대와 30 대에 치명적이었고, 이는 노동력과 인구수에 큰 피 해를 입혔다. 1920년, 문제해결을 위해 43대 국회의원이었던 마츠시타 테이지는 스페인독감을 위한 전문연구시설 설립을 주창했고, 국회는 곧 특별위원회를 소집 하여 이 안건을 논의했다. 이 특별위원회는 야당과 여당 의원들, 의학, 과학계 인 사들, 정부 기관장들로 이루어졌다. 본 연구는 위원회 참석자들의 인적 네트워크 와 이해관계를 토대로, 마츠시타 테이지의 초안이었던 '스페인독감을 위해 전문연 구시설 설립'이 어떻게 '스페인독감에 대한 연구'로 변했는가를 분석한다. 이에 제 국정부와 부서 간 구조적 비완전성과 정치-과학계의 일선, 정당정치가 20 세기 최 악의 유행병조차 일개 ‘연구를 요하는 사회문제’로 축소했음을 주장한다.

주제어: 일본제국, 스페인독감, 전염병예방, 정당정치, 검역 